\title{
Gender in the Macedonian Adolescent Literature
}

\author{
Jovanka Denkova \\ Goce Delchev University, Faculty of Philology, Krste Misirkov, Zeleznicka bb, Shtip, Macedonia
}

\begin{abstract}
In this paper we refer to gender differences in the Macedonian literature for young readers, from teens. The approach will keep on several novels of postwar Macedonian literature for young people, and would be reviewed novels by writers from different generations, in order to see the approach to the treatment of gender differences. It is very obvious that at the writers of the older generation, the treatment of female adolescents is more patriarchal, in the sense that female adolescents as subservient to the authority of male adolescents. Their characters in the works themselves as marginalized, do not have equal representation in action, nor leave the opportunity to take some concrete action. The research on the particular material should show that unlike writers who work in the postwar period, when the issue of gender, sexuality or identity of the female adolescents is quite neglected, in the 80s appears a new generation of authors who are looking for the first time to those subtle differences in sensibility of young adolescents. But research also looks at the relationship between parents and family, to female adolescents, on the one hand and to the men on the other side.
\end{abstract}

Keywords: adolescence, Macedonian literature for youth, gender approach

\section{Introduction}

One definition of Gender Role according to the Oxford Dictionary of Psychology is, ,a set of behavior patterns, attitudes and personality characteristics stereotypically perceived as masculine or feminine within a culture“. [1]

There are many theories concerning gender roles and many common assumptions about them as well. One popular theory developed by Bem (1981) is referred to as Gender Schema Theory. Gender Schema Theory asserts that children learn gender roles from society and that the sex roles they learn from society they then mold into gender schemas that they attribute to themselves [2].

The manner in which genders are represented in adolescent literature has the capability to impact young adults' attitudes and perceptions of gender-appropriate behavior in society. As author Mem Fox (1993) states, „Everything we read...constructs us, makes us who we are, by presenting our image of ourselves as girls and women, as boys and men [3]. Without doubt, the impact of the school and literature in the formation of identity among youth is great, especially in forming their views on gender differences. According to Jameson (1981) in creating the story, the writers decide which characters and themes have an important place in their cultural awareness, with certain exceptions it is the cultural norm to illuminate action policy unconscious [4]. Certain authors as Svetlana Tomić (2012) [5], point to some feminist [6]. and sociological analysis (Burdije 2003; Guillory 1993) [7]. of culture according to which it was determined that there is a link between patrijarhalcentrich ideology, patrijarhalcentrich education system and patrijarhalcentrich canonization which is not so naive. She points out the predominance of the male gender, his powers and knowledge. According Guillory (1993), if through such patrijarhalcentrich stories in literature passes silently, there is a danger that they can be accepted as inevitable, so the school has a social obligation to give students access to those works which are an important and significant part of their culture [8].

\section{Gender in the Macedonian Adolescent Literature}

First, we turn to the novel "Beloto cigance" ("White Gypsy") (1966) by writer Vidoe Podgorec (1986), where the main character is a boy Taruno who as a baby was protected from the midst of the gypsy rug. In everyday events, his company are blind boy Rapush who plays the violin and girl named Nasiha, all affectionate in game, the flowers and admiration for the beauty of nature). She is represented as a cute girl with a dark chocolate face, peer and friend of Taruno and Rapush. She often suits from village to village along with Rapush and his mother - Aunt Azha, which was oracles and their envisioned future of the country women. She had a good heart, but often knew and tenacity and opposes others. She was a good friend and together with Taruno and Rapush were much occupied with their children's games [9].

Although she is not blind to the situation in which live gypsy rug, she appears in the novel as the most faithful companion of Rapush thru the villages. Although not initiated any action in the novel, her character the author served to him to express only those first gentle, subtle feelings of fondness that Taruno feels ti her. He respects her opinion and in burdensome situations where children and villagers offend and chase them because of gender differences and prejudices, Nasiha acts as a kind of moral support. But as mentioned earlier, she is not the holder of any action.

According to Jacobs, young adults may be particularly susceptible to gender portrayals in literature as they work through a stage in life in which they are searching to define themselves. Gender stereotypes in literature can prevent young adults from reaching their full potential as human beings by depriving them of suitable role models and reinforcing age-old gender constraints in society. These stereotypes exist for both genders and are equally dangerous. While girls are portrayed as passive and weak, boys and men are rarely presented as feeling and vulnerable human beings [10]. 


\section{International Journal of Science and Research (IJSR) \\ ISSN (Online): 2319-7064 \\ Index Copernicus Value (2013): 6.14 | Impact Factor (2014): 5.611}

The Fellowship is a set of persons of the same or opposite sex, whose collective behavior is determined by internal voluntarily accepted rules. The rules of the group often emphasize a moral norm, which at the time was current in society and group endeavors that rule strictly respected. The group can be with differentiated or undifferentiated gender, created with clearly defined purpose, with a simple structure and strong hierarchy with defined gender roles [11].

In the novel „Golemi i mali“ („Big and small“)(1966) by Bosko Smakoski (1990) is shown just such a mixed crew (although prevailing the male members), which manifests itself as a moral corrective to adults. Buba is the only girl who stand out in a group of male friends and with her stand sometimes knows to resist to friends when they are not right, and to adults in defense of her companions. It is evident that although she freely manifests their position, however it works a little pressured and with restraint, unlike the boys who have complete freedom in action and behavior [12].

The novel „Bubreze“ („Kidney“) of Kata Misirkova Roumenova (2001) [13], in a leading role sets young girl Elena, who suddenly found trapped in a love triangle which least wants, especially since her friend Barbara, who is in love with her boyfriend Vojdan, is killed in stampede in the disco. These events will cause profound mental-emotional tremors in her young and fragile soul, but Elena is strong enough to get out of this vicious circle and regardless of drugging Vojdan, the dramatic events in her family (divorce, strikes, and cancellations of work), it remains true to itself. Through sport and friendship with a boy like her (Umprofor boy Ulfan) away from all the problems and taking its own life and future in her hands.

The novel „Kuklite na Rosica“ ("Rosica's Dolls") (Nikolova: 2003) [14], is one of the few Macedonian historical novels written by a female author. Its distinctiveness on the one hand, is the selection of a national historical subject by a woman author, and on the other hand, that the main character in the historical events described is also a woman. The events taking place in it are placed in the second half of the nineteenth century, from 1879 to 1899 . Divided into three chapters, each of which deals with the beginning of a decade, the novel shows a stormy and still insufficiently clarified developments related to the beginnings of the creation of the Macedonian national identity. All those who parade through the pages of the novel are large man, already known (for good or bad) in Macedonian or Bulgarian history of this period - Dimitar Miladinov, Marko Cepenkov, Kuzman Shapkarev, Gorgija Pulevski, Prlicev, Bishop Nathaniel Kuchevishki of course, Goce Delcev, a character who at the end of the novel gets a special meaning and symbolism. Amid all their big talk and actions, and big plans for the liberation of Macedonia, the main character (the subject) of Nikolova and witness to most of these events is mute girl Rosica. Rosica character as a subject in this novel, contributes further to his uniqueness, diversity compared to other historiographical prose in Macedonian literature, functioning on several levels. First, into the historical framework she brings personal history, a history that is present in people's memory, which remained secondary or less relevant than (official) history. In the first chapter, entitled "Separation" it said: "Rosica left the past behind. But instead remembering, she first had to learn to speak" (p.11). Inability to speak for Rosica is an additional factor that increases the feeling of forgetting by the history as fate determinant for the woman - she has no access to the language as a way of communication and therefore she remains on the margins of history that they have created, she is always there to convince, but never enough to present to notice what she witnessed, let alone participate in it. However, Rosica exclusion of the great history does not mean her lack of her own history. Inability to enter in the language that works, she compensate or be replaced by a different one - making dolls. Through her dolls, Rosica not only becomes a part of this universal discourse, but she intervened in recorded history, with the choice of which doll will do, and how the doll will display man against whom he has made, because she cannot do doll if there is no character for her: „And the dolls were beings and what will it being be without character and biography“(p.20). Thus, through dolls, Rosica tells history as she sees her, and this narrative "provides a link between the private and public history because all historical events are someone's direct experiences“. Through puppets, Rosica transfers her point of view on things, her image for the people she encounters, and their desires about what she would like them to be. At the end of the novel, when on the p. 270 we reveals her surname, Rosica becomes self-conscious entity - she finally becomes an individual, an active participant rather than just a silent observer of events. Her personal narrative becomes part of the history through the act of awakening, awakening of the female body and first through the experiencing of physical love with Andon, then through pregnancy, the symbiosis of her body with new life. This transformation reveals and another level to which the entity Rosica operates, the level that put her in position as a kind of metaphor for the entire Macedonian nation in the historical moment in which she is situated. Thus, the history of the Macedonian people is actually identified with the history of women, especially women's writing - here's marginality in relation to the big (male or national) discourse. The novel "Rosica's Dolls" by Olivera Nikolova conveys Macedonian fate closely, making personal story of the Macedonian golgotha. Mute and raped Rosica becomes a metaphor for violated and stiff Macedonia. The message from this work, the author Olivera Nikolova transfers starting from history where she recognizes the continuity of long struggles for national freedom and the desire for emancipation. Through the past, she recognizes the present and through the present feels the future, because our present was the future of our ancestors. And the future of our descendants, we dream today, in our present. With each passing moment we spend in the past, and again this past becomes a factor for survival of those who will come after us (Siljan, 2008) [15].

"Umnite izmisluvaci" ("Clever inventors") (2002) is a novel by Violeta Martinovska [16], which tells about life in the neighborhood called Magyar maalo, the rrelationship of children to adults and vice versa, everyday coexistence which they build common, school desks that teach children to faster maturing and taking place in the adult world. The novel consists of 21 separate stories through which will walk thru the stage the four main characters: Zlatokosa (Goldy), Vice

\section{Volume 5 Issue 2, February 2016}




\section{International Journal of Science and Research (IJSR) \\ ISSN (Online): 2319-7064 \\ Index Copernicus Value (2013): 6.14 | Impact Factor (2014): 5.611}

tocakot (Victoria) Caki Hrabrata (Sonia) and Magyar (Tony) (Mladenoski, 2005) [17].

Despite their baptized names, they mutually rename each other according to their individual characteristics. So, Victoria, gets her name because she is constantly on her bicycle, Sonja - because she is brave and fast, Tonyaccording to neighborhood of origin, and Zlatokosaaccording to her hair. Precisely through their naming can be seen the gender approach in the novel, that equality between boys and girls: „And you, Sonja, we will call you CAKI BRAVEONE "... You are brave like a Turk and you beat beter than male. You're especially proud of the feminine "(10). Another example that shows equal gender access is when the boy Nikola offers Vice Bike to be his sister, and he to be a brother to her, of course secretly, until they get a real sister and brother: „That day I felt strange. Suddenly I had a brother. Nichola is now the most important name in class "(50). Another point in this equal gender aproach between the characters is one of their everyday children's games, playing with marbles, which are usually considered exclusively "man's game" because the girls play it very rarely: , I always win with marbles ... I was very precise with marbles "(28); "I had no equal in the marbles in the neighborhood. I've no idea how I could be so precise with them (166-167)“. In this context, it is interesting to note that Vice Bike gives to us about how her parents understand her obsession with marbles. In fact, there was a patriarchal relationship by her mother, which a dim view of it, unlike her father: "My mother was very angry because of the marbles... So I had to hide them somewhere. My father did not scold me about them and gave me some more homegrown marbles "(166-167). Finally, the last point in which is evident gender approach among the children of the street, is the moment when they say all the funny names:

- There are many funny names ... Ljuta, Limonka ... Rose, Loza ... - Magyar was grinned.

- You are saying only female names. There are also funny male names. For example, Herby, Flower, Pearl, Easterner - respond Caki "(180-181).

Contrary ridicule tones of Magyar to "funny" female names with floral overtones, as a feature of the feminine principle / gender, Caki opposite him "male funny" names, also with floral overtones, and in some way feminizes them.

„Zimski detektivi“ ("Winter Detectives") is a novel by Olivera Nikolova (1986) [18], which represented a group of two boys and a girl, who exactly initiated the girl take concrete action - finding sweater domestic helper lights in the cave near the city. After the disappearance of Svetlana in the depths of the cave, the boys, both of them, unconsciously and secretly in love with her because of her independence, they start into action to rescue. Meanwhile, Svetlana reveals the tragic fate of the man who kidnapped her in the cave, Mile, who because of the cruelty of life and people was desperate to get away from everyone. That it, with her great suggestive power and human understanding, will return him to the people.
In the novel "Ljubov plus" ("Love plus") by Hristo Petreski (1990) [19], the action begins with the narration of the protagonist Vasco who was sent to action by parents in order to domesticate him. There was not like in the army, but was similar and had to respect the house rules. He actually does not know why he goes there, but resigned when sees that there are female potential in the district, he says, and would expel two or three weeks to become stronger and enjoy of another's account. He had gone to catch a good girl and to catch a sun ten like he was at sea. His casual attitude towards the environment will be disturbed by the affections which he felt toward the girl Zeljka also forewomen. There occurred and their first kisses for which the main character says that were true opium, something that will calm him down, look for all subsequent action days and nights. The girl Zeljka is very independent and that is what attracts Vasco to her and when she is declared for best speaker, he will even felt jealousy towards her. He especially becomes jealous when he notices that other men are increasingly turning their eyes to her. Their love ends when Zeljka must go home because of the illness of her sister, after which Vasco will move to work as speaker of Popova Shapka, where they meet and bring the girl Ranka. The relationship with her will take more than the duration of the action, but what is important is that Ranka and Zeljka actively participate in the relationship with Vasco, actively participate in the action, in work as announcers and even their male envy them. The girls work alongside the boys and show even more valuable.

The novel "Rock otter" by Vesna Acevska (1993) [20], begins with the attitudes and opinions of one of the main members of the rock band, Kire, about public appearances and that each of us at least once had one important performance whether the action will take place at home, at school, behind the scenes, sea, stadium field. Whatever will be the outcome of the public appearance, it is still important to participate. This novel talks about the biggest life adventure that has been committed by a group of boys and girls in their seventeen years - when playing and singing have to show on the big stage. Kire along with his companions Ljupche, Mete, Igor, Vicky, Vale, Ville, devising a plan to prevent parents to go to the upcoming audition which had signed, certainly aided by the brother of Kire, Sime. Their parents also wanted to join the action, and agreed plan for the big event called "Plan for the switch to Otter Rock Group", or wanted to collect all the instruments and together with the young man to go to the Youth Club. However, young people wants to be independent, and even more because of the fear of public appearance and fear of defeat at the audition, at all ways they try to distract adults from the event. At the most in that intention helps the girls of the group. On the performance Ville, Vale and Vicky were beautifully dressed in shirts in different colors on shirts, jackets with embroidery, strung beads and coins. From such decorations also to was made and the scarf that each of them had in his forehead. All in "Altanche" were surprised by their beauty and even their friends. So, after every success, sitting in their garage with Ljupche, Willie, Vicky Mete, Igor and Jack, they wondered what spans them. Each of them gave the answer what is the magic of their success. For Mete it was the music, for Ville the common sense, Vale replied that for her it is a common childhood elapsed, for Igor it was their neighborhood, for 


\section{International Journal of Science and Research (IJSR) \\ ISSN (Online): 2319-7064 \\ Index Copernicus Value (2013): 6.14 | Impact Factor (2014): 5.611}

Wiki - school, but for Ljupche - it was first love. In fact, that is where this group of young people exists and daily companion, growing and maturing - together. Therefore, throughout the novel is not observed any inequality between boys and girls.

"Super devojce" ("Super girl") is a novel by Tome Arsovski (1994) [21], in which the main protagonist is Sandra. She is the "super girl" girl for example to anyone, that is to say, a girl who loves school, and also respect teachers and her comrades, respect her parents who care much for her and her brother Dejan, listens and respects the advice of parents and listens the advice of her brother, though smaller of her. But uptake of puberty except that gradually begins to change her appearance, gradually begins to change her behavior and begins to not hear interlocutors, she is becoming more impulsive, begins to offend and so on. Although she knows that it is not a part of her behavior and does not want to do that, but something is stronger than her and she behaves exactly like all teenagers: „,-Listen - said Dad with last patience supplies. - Do not talk to me like that, stop, okay? I'll clap you! - I do not know what came over me, to defiance him, I stood in front of him and watched his trembling hand, barely refrain. - So come on, hit me, you're stronger, right? Slap burst me like a cannon. I only shrieked, twitched and I immediately stood up again: - Hit me again, Dad, you're stronger! Beat up your imp, strike me!".

These novel shows us the phase of transition from child to adolescent, and that we see when Sandra violates orders given by her parents that she should always be home before midnight, the way she behaves with parents, capturing and breaking with her boyfriend (Dushko), the way of dressing, etc.: "Women's fashion is changing swiftly. Instead the former rajf, now in hair we put glasses. Betty put them anyway, over his forehead. As if sunglasses are on duty when cooked "yellow star" - meaning the sun to protect your eyes from harmful radiation." Besides she emphasizes women's fashion in the coming narrative sequences, Sandra talks about the relationship with her mother, the defensive attitude of her brother to her. On the other hand, is an assumption of her father that she could be the cause for breaking up with her boy friend even before he hears her side of the story.

Here is Sandra cconversation with her mother: "... We talked like two friends, like two adults, which I liked scary. So I was getting carried away as ever and I began to criticize the boys, their flatulence, their toughness especially that they want to show off in front of girls. All make thugs, macho men, - but they are fleeing from girls as in horror! .. - This time also, mom "read me." Breaking up with Dushko with a super girl, that Sandra, will bring her much pain, talking to parents in a language they are not fitting, insults to friends etc. However she exceeds it by their help and of course with the help of her brother Dejan who affectionately calls her Cale. He, though smaller than her, still knows how to give her comfort, he will do everything so she can be happy even if it means to beat the person who hurts her: - Dushko!? Well, I will kill him! rushed Dejan. - Do you want me to kill him? - Good Dejan, do not interfere - dad stopped him ...Did you gave him a reason for that? - I!? - I felt offended. - It would be the last thing she would do it! Betty is the reason a hundred percent!
- Betty? - shouted Dejan. That sack of bones ... Sandra, do you want me to call Boshko and Vlado? We will wait her in the dark, sack on her head - ugh! If there are four thousand bones of it, we will make forty thousand "... That was her big smaller brother with his ingenious ideas.

Denigration of Dushko and Betty, which is cause for termination of Sandra and Dushko are made on the basis of their physical appearance. In conversation with her mother, Dushko's degradation switches to all male kind.

"Prolet zad mojot prozorec" ("Spring behind my window") (Arsovski, 2005) [22], and „Mladi i divi“" ("Young and Wild") (Arsovski, 2007) [23], are also novels by Tome Arsovski in which as a narrator (storyteller) occurs girl Dana girl and narration in the first person singular. Each chapter is particularly telling of a story of the main character in the novel. Dena is a girl who has over sixteen and seventeen.

She is the daughter of divorced parents, the mother who is a tour guide and she is constantly on a trip. As such, she rarely is at home and very devotes very little attention to her children. According to Brandt and Thomas, working experience with single mothers has a profound impact on children/youth. Namely, citing a series of studies, they emphasize that children brought up by single mothers contributes to the low-income family, which in turn reflects on the children (especially in childhood) on multiple levels: learning outcomes, socio-economic, socio-psychological results (2014) [24].

In the case of considered novels by Tome Arsovski, the "Spring behind my window," we are witnessing the girls who are left alone, workload mother who is trying to provide a secure life for the three, as well as awareness of days that alone (without Dad) will handle.

Although the novel does not show the divorce and girls do not go through it, when the novel begins, parents are already divorced, but precisely by not speak directly on the subject, the author shows that life continues after the divorce of parents (Wells, 2003) [25]. During this novel, the father is absent and it will allow females to develop their personalities, but after his returning in the second novel, he remains in the shadow (Alcott, 1998) [26]. In this context, already in the second novel, "Young and wild" we are about to see the two sisters in a family in which the father returns after a certain period, they are particularly happy, but we can also see their desire to work and earn. Such an attitude towards their life due to the lived, loneliness while their mother was absent and divorced from their father: "We can do it, Mom, right? Together we can do it without a father ... (53)."

\section{Conclusion}

The analysis of a number of novels of Macedonian literature for children and young people, leads us to the conclusion that our assumption was originally correct. Namely, it turned out that the writers of the older generation have more patriarch gender approach, particularly in cases prevailing images of 


\section{International Journal of Science and Research (IJSR) \\ ISSN (Online): 2319-7064}

Index Copernicus Value (2013): 6.14 | Impact Factor (2014): 5.611

boys who are carriers of action, their characters are magnified, they are imposing on their strength, power, wit et seq., in relation to women characters who are marginalized and placed in the shade, presented as weak, too delicate and emotional, as characters who can't decide for themselves, etc. ("Beloto cigance","Golemi i mali", "Kuklite na Rosica").

But this situation changed significantly in the works published by the 80 s onwards. In these cases females have equal representation, there are many novels in which the main characters are girls who flattered his determination and readiness for action ("Zimski detektivi"), a willingness to find their place in society and not allow negative things to to confuse future ("Bubreze"), who even physically are equal to boys ("Ljubov plus") as characters strong enough to resist the vices of today, drugs and alcohol, to fend for themselves, to employ and work ("Mladi i divi", "Prolet zad mojot prozorec"), who are free to express their feelings about the boys, even at the cost of physical punishment by parents ("Super devojce") and free to rename members of the masculine gender with ridicule connotation.

This free, even we can say feminist approach of our writers for young people, gives hope that future generations will be able to develop without any prejudice and stereotypes, regardless of gender.

\section{References}

[1] A. Soni, "Gender images and identities (de) constructed in the Young Adult English literature in global perspective", Vol.7, 2, 2014, http://www.englishcyberliterature.net/01.pdf, accessed on 09.01.2016.

[2] S.L. Bem, "Gender schema theory: a cognitive account of sex typing”. Psychological Review.88(4), 354-364, 1981.

[3] M. Fox, "Men Who Weep, Boys Who Dance: The Gender Agenda Between the Lines in Children's Literature.” Language Arts 70, p. 84-88, 1993.

[4] F. Jameson, "The Political Unconscious: Narrative as a Socially Symbolic Act", Ithaca/New York, Cornell University Press, 1981.

[5] S. Tomić, "Price srpskih klasika Laze K. Lazarevića i Ive Andrića: dva primera patrijarhalno-stereotipnog konstruisanja likova devojcica", Detinjstvo, Novi Sad, 2, p.41, 2012.

[6] R. R. Warthol, \&P.D. Herndl, "Feminisms: An Anthology of Literary Theory and Criticism", New Brunswick, New Jersey, Rutgers University Press, 1997.

[7] P. Burdije, "Pravila umetnosti, Geneza i struktura pola književnosti", Novi Sad, Svetovi, 2003; J. Guillory, "Cultural capital: The problem of Literary Canon Formation", Chicago and London, The University of Chicago Press, 1993.

[8] J. Guillory, "Cultural capital: The problem of Literary Canon Formation", Chicago and London, The University of Chicago Press, 1993.

[9] V. Podgorec, "Beloto cigance", Nasa kniga, Skopje, 1986.

[10]K. Jacobs, "Gender issues in young adult literature", https://scholarworks.iupui.edu/bitstream/handle/1805/13
35/Gender\%20Issues\%20in\%20Young\%20Adult\%20Lit erature.pdf?sequence $=1$, accessed on 09.01.2016

[11] D. Krstić, "Psiholoski recnik", Beograd, Vuk Karaђić, 1988.

[12]B. Smakoski, "Golemi i mali”, Nasa kniga, Skopje, 1990.

[13]K. Misirkova Rumenova, "Bubreze", Detska radost, Skopje, 2001

[14] O. Nikolova, "Kuklite na Rosica", Kultura, Skopje, 2003.

[15]R. Siljan, "Makedonski pisateli i dela", Matica Makedonska, Skopje, p.202, 2008.

[16] V. Martinovska, "Umnite izmisluvaci", Detska radost, Skopje, 2013.

[17]R. Mladenoski, "Cekajki ja egzegezata", Sovremenost, Skopje, 2005.

[18] O. Nikolova, "Zimski detektivi”, Misla, Skopje, 1986.

[19]H. Petreski, "Ljubov plus", Detska radost, Skopje, 1990.

[20] V. Acevska, "Rok vidri”, Detska radost, Skopje, 1993.

[21]T. Arsovski, "Super devojce", Detska radost, Skopje, 1994.

[22] T. Arsovski, "Prolet zad mojot prozorec", Detska radost, Skopje, 2005.

[23] T.Arsovski, "Mladi i divi”, Makavej, Skopje, 2007.

[24] J.E. Brand and J. S. Thomas, "Job displacement among single mothers: Effects on Children's outcomes in Young Adulthood", American Journal of Sociology, Vol.119, No.4, p.960, January 2014.

[25]A. D.Wells, "Themes found in Young Adult Literature: A Comparative study between 1980 and 2000", University of North Carolina, Apr 2003. http://www.ils.unc.edu/MSpapers/2861.pdf Web. 05.11. 2015

[26] L.M. Alcott, "Little women", Valerie Alderson, editor, New York, Oxford University Press, 1998.

\section{Author Profile}

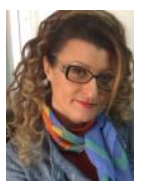

Jovanka Denkova received the PH.D. degrees in Faculty of Philology "Blaze Koneski", Kiril and Metodiys University I Skopje, Macedonia in 2008, on a theme by Children's literature. During 2008-2016, she works at Faculty of Philology, Goce Delchev University-Shtip (Macedonia), as a vice dean for education, and dean (2012-2015). At the moment she is Associate professor. She wrote over 120 papers on the children's and adolescent literature. 